\title{
New Public Management in Bangladesh: Policy and Reality
}

\author{
Farhana Ferdousi*, Lisheng Qiu \\ Department of Political Economics, School of Economics \& Management, Wuhan University, Wuhan, China. \\ Email: *dfferdousi@gmail.com
}

Received July, 2013

\begin{abstract}
New Public Management (NPM) is a management philosophy used by the government since 1980s to modernize the public sectors. Many developed and developing nations are now experimenting about the applicability of NPM in their context. In Bangladesh, NPM reform ideas have also been recommended by international donor agencies as well as numerous reform committees but yet the country has hardly made any progress in establishing effective public management. This paper attempts to identify some administrative reforms in Bangladesh that have the spirit of NPM as well some peculiarities that threaten successful implementation of NPM in Bangladesh. It is argued that state incapacity, bureaucratic failure and donor-driven reform policies are responsible for the failure of implementation of NPM in Bangladesh. Therefore, to establish efficient public management or to follow NPM model, Bangladesh need to have solid institutional frameworks, sound rule of law, proper control structures, appropriate checks and balances, effective civil service system, appropriate accountability and transparency; and for these political leaders, bureaucrats and donor-agencies have to work in line.
\end{abstract}

Keywords: New Public Management; Administrative Reforms

\section{Introduction}

Since Bangladesh gained independence in 1971, reforming the administrative state, inherited from the colonial authorities, has become a major aspect of the country's quest for development. Various governments, be they military or civilian, have made reforms a major priority on their developmental agendas and have, therefore, expended significant resources, both human and financial, in these efforts. The preoccupation with reform stems from the expectation of establishing an effective system of government and resolving the problems that had hindered its development as a province of Pakistan for twenty-four years. At the end of forty years of its independence, the country has hardly made any progress and still suffering for the absence of good governance, fragile economy, poor law and order situation, unstable political system, uncontrolled corruption, unreliable social services and inefficient bureaucracy etc. Interestingly, since independence the government constituted 17 reform Commissions or Committees with a view to reorganize/reform civil service and public sector. More than 20 reports on Public Administration Reform have been prepared by these Commissions and Committees and some of those reports were prepared at the initiative of some of the important development

\footnotetext{
"Corresponding author.
}

partners, particularly the World Bank, the United Nations Development Programme (UNDP), the Asian Development Bank (ADB), the Department for International Development (DFID), and the US Agency for International Development (USAID) [1]. But the recent history of Public Administration Reforms has become nothing more than a sequence of reform studies and proposals, with little evidence of real change. The present study is an attempt to find out some problems regarding implementation of new public management, the current trend in the world to reform and manage the public sectors.

\section{Concept of New Public Management and Administrative Reforms in Bangladesh}

In response to economic, institutional and ideological changes, as well as criticisms of inefficient and costly public sectors, public sector reform has become an international phenomenon [2,3]. As part of these reforms, a paradigm of public sector management known as new public management (NPM) has emerged in OECD (Organisation for Economic Co-operation and Development) countries and elsewhere [3-5]. Therefore, the New Public Management (NPM) can be defined as a management philosophy used by governments since the 1980s to modernize the public sector. It is a broad and very complex term used to describe the wave of public sector 
reforms throughout the world since the 1980s. The main hypothesis in the NPM-reform wave is that more market orientation in the public sector will lead to greater cost-efficiency for governments, without having negative side effects on other objectives and considerations. According to the OECD [6], "a new paradigm for public management" had emerged, with eight characteristic "trends" (listed in modified order, to range from internal to external concerns):(1) Strengthening steering functions at the center;(2) Devolving authority, providing flexibility; (3) Ensuring performance, control, accountability;(4) Improving the management of human resources;(5) Optimizing information technology; (6) Developing competition and choice;(7) Improving the quality of regulation; and(8) Providing responsive service.

States opting for NPM have not necessarily incorporated all these elements of NPM. Most countries have been selective in incorporating those elements of NPM that they felt were best suited to their individual administrative milieu, economic and social condition, and governance culture. NPM has also been an evolving concept with states experimenting with approaches and mechanisms. These include policy guidance to the government through stakeholders' councils (the 'deliberations councils' of Japan) for the management of sectors, industries, issues etc., departmental boards as in Britain, policy analysis and evaluation cells as in Japan and other countries, the minister's ability to reach beyond the senior bureaucrats to 'buy' policy advice, and corporatization of government functions, as in New Zealand, e-governance, as in Britain, Malaysia, china, and several Indian states, and a whole host of management tools and techniques like Total Quality Management (TQM), operations research, Human Resource Development (HRD), market research, etc.[7]. In the 1990s, if not late 1980s, developing countries began to adopt selected elements of NPM [8-10]. However, research on the implementation and effectiveness of NPM in developing countries is still going on.

By the early 1980s, when the world is swept by the necessity of modernizing public sectors, Bangladesh with no exception, had observed the public administration system in its highest level of inefficiency that not only worried national planners but also international donor agencies, which were financing different projects under structural adjustment plans. Therefore, NPM-style reforms strategies have been suggested by various study reports. Careful analysis of the recommendations provided by various study reveals the presence of NPM systems in Bangladesh (Table 1). Privatization of Public enterprises, contracting out of public services, users' fees, reduction of manpower in the public sector, meritocracy in the public service, professionalism, performance standards, citizen's charter, market-based salary structure, devolution of authority to local elected bodies, e-governance, and combating corruption are some of the recommendations that reflects the spirit of NPM [11]. The present government is now giving stress on information technology which is one of the prerequisites of NPM. All these efforts have the reflections of the OECD listed trends of NPM.

Being influenced by the internal and external pressure, although several attempts have been made to introduce reforms in public management in Bangladesh, but most of the reform initiatives were either failed to produce significant results or manipulated by the politically motivated governments in their favor and successive governments appeared to be comfortable with the traditional approach. As a result, huge amounts of resources were wasted in examining the system and developing recommendations, which were never implemented sincerely

\section{Perspectives in the Failure of $\mathbf{N p m}$ Reform in Bangladesh}

A review of following literature [1,12,14-22] suggests some factors which are responsible for non-implementation of major reform initiatives in Bangladesh. Summarizing their findings this paper categorizes the major reasons of failure of implementing NPM in Bangladesh in the following ways:

1. Incapacity of the state in terms of ;

- Political incapacity which is manifested by criminalization of politics, clientelism that exacerbated nepotism, favoritism \& factionalism.

- Institutional incapacity that results in breakdown of law, spread of massive corruption in accumulation \& distribution of resources.

- Technical incapacity which increases the absence of appropriate manpower, lack of performance control and accountability.

- Administrative incapacity exhibited in the state's failure to provide basic public goods and services, economic infrastructure, accountable judiciary etc.

2. Bureaucratic failure to implement innovative and changed policies because of

- Resistance from senior bureaucrats

- Reform attempts are short-lived

- Non-inclusion of stakeholders in decision making process.

3. Failure of donor agencies to pursue reform either because before the prescribed country realize the need for reform, reform agendas are imposed on her or reform policies are over-ambitious, ill-conceived \& not-adopted to local context and political reality. 
Table 1. Some important administrative reforms in bangladesh which have the overtones of NPM.

\begin{tabular}{|c|c|c|}
\hline Committees/ Commissions/Study Groups & Focus & Recommendations \\
\hline $\begin{array}{l}\text { Martial Committee on Examining } \\
\text { Organizational setup of Ministries, Divisions, } \\
\text { Directorates and other Organizations, } 1982 \text { [12] }\end{array}$ & $\begin{array}{l}\text { Reorganization and } \\
\text { Rationalization of manpower } \\
\text { in public organizations }\end{array}$ & $\begin{array}{l}\text { Reduction of the size of the government; reduction of layers } \\
\text { for decision making; delegation of administrative and } \\
\text { financial powers down the hierarchy }\end{array}$ \\
\hline $\begin{array}{l}\text { UNDP-sponsored Public Administration Sector } \\
\text { Study,1993 [13] }\end{array}$ & Civil service & $\begin{array}{l}\text { Performance management system; rationalization of civil } \\
\text { service structure; elimination of redundant government } \\
\text { functions; merit-based selection and promotion; } \\
\text { strengthening Public Service Commission }\end{array}$ \\
\hline $\begin{array}{l}\text { World Bank Study: Bangladesh Government } \\
\text { That Works Reforming the Public Sector,1996 } \\
\text { [14] }\end{array}$ & $\begin{array}{l}\text { Civil service, public } \\
\text { enterprise, NGOs }\end{array}$ & $\begin{array}{l}\text { Redefining frontiers of the public sector; enhancing level } \\
\text { and nature of accountability and responsiveness of public } \\
\text { organizations to different stakeholders; streamlining } \\
\text { regulations, laws and processes; maintaining an efficient, } \\
\text { committed and professional public service }\end{array}$ \\
\hline $\begin{array}{l}\text { Public Administration Reform Commission, } \\
2000 \text { [11] }\end{array}$ & $\begin{array}{l}\text { Administrative structure for } \\
\text { improving the quality and } \\
\text { standard of service, } \\
\text { transparency and efficiency }\end{array}$ & $\begin{array}{l}\text { Determination of missions of public offices; improving the } \\
\text { delivery of services; reforming the civil service; formation } \\
\text { of the professional policy making group (senior } \\
\text { management pool); reorganizing institutions and } \\
\text { rationalizing manpower; restructuring field administration } \\
\text { and decentralization; establishment of an independent } \\
\text { commission against corruption; establishment of criminal } \\
\text { justice commission; establishment of the Office of } \\
\text { Ombudsman; reducing wastage and promoting value for } \\
\text { money; strengthening parliamentary oversight; facilitating } \\
\text { private investment }\end{array}$ \\
\hline
\end{tabular}

\section{Conclusions}

From the above discussion it is evident that some administrative reforms in Bangladesh, specially provided by World Bank and Public Administration Reform Commission, have the reflection of NPM. But Bangladesh is still far away from those countries which implemented NPM successfully like, UK, New Zealand, USA, etc. The reason behind this may be that different countries started from different contexts in terms of the level of economic development, the existence of the rule of law, the level of administrative infrastructure and sate capacity and efficiency to implement reforms. Therefore, it is possible that NPM might potentially provide some benefits to Bangladesh. Yet the peculiarities of the Bangladesh context, such as the high degree of politicization of the bureaucracy, the bureaucratic domination of the system, lack of political commitment toward implementing reform policies, incapacity of the state in terms of institutional, technical, administrative and political factors, deteriorating law and order situation, misuse of power for personal and political gain by members of the ruling party may not bode well for NPM measures. Moreover, clientelist nature of politics and factionalism in public sector also threaten implementation of any reform initiatives, if the interests of particular groups are not protected by that reform. 'Sound policies will not sound well if it is not implemented well' is the basic reason of failure to implement NPM-style reform in Bangladesh. Moreover, donor imposed reform initiatives have very few records of success as they are reluctantly accepted by the government. Ray, Turner and Hulme also argued that donor-driven reform programs are counter-productive and may even contribute to reduced performance and political instability [23,24]. Therefore, to establish efficient public management or to follow NPM model, Bangladesh needs to have solid institutional frameworks, sound rule of law, proper control structures, appropriate checks and balances, effective civil service system, appropriate accountability and transparency; and for these political leaders, bureaucrats and donor-agencies have to work in line; otherwise NPM would be present in policies only.

\section{REFERENCES}

[1] United Nations Development Programme (UNDP), "Public Administration Reform in Bangladesh," SURF. Bangkok, Thailand, 2004.

[2] L. Bennington and J. Cummane, "The Road to Privatization: TQM and Business Planning,” International Journal of Public Sector Management, Vol. 10, No. 5, 2000.

[3] O. E. Hughes, "Public Management \& Administration," 2nd ed, London: MacMillan, 1998.

[4] D. Osborne and T. Gaebler, "Reinventing Government: How the entrepreneurial Spirit is Transforming the Public Sector,” Ringwood: Penguin Books, 1993.

[5] C. Pollitt, "Justification by Works or by Faith?: Evaluating the New Public Management,” Evaluation, Vol. 1, No. 2, 1995. doi:10.1177/135638909500100202

[6] Kickert and J. M. Walter, "Public Management and 
Administrative Reform in Western Europe,” Edward Elgar, 1997.

[7] Government of India, "Organisational Structure of Government of India,” Second Administrative Reforms Commission, Thirteenth Report, April, 2009.

[8] R. Common, "Convergence and Transfer: A Review of the Globalisation of New Public Management," International Journal of Public Sector Management, Vol. 11, No. 6, 1998. doi:10.1108/09513559810244356

[9] G. A. Larbi, "Institutional Constraints and Capacity Issues in Decentralizing Management in Public Services: the Case of Health in Ghana,” Journal of International Development, Vol. 10, No. 4, 1998.

[10] R. Samaratunge and O. Hughes, "Development and New Public Management: Partners in the 21st Century," Sri Lankan Journal of Management (forthcoming), 2002.

[11] Government of Bangladesh (GoB), "Report of Public Administration Reform Commission,” Dhaka: Bangladesh Government Press, 2000.

[12] Sarker and A. Elias, "Administrative Reform in Bangladesh: Three Decades of Failure," International Public Management Journal, Vol. 7, No. 3, 2004, pp. 365-384.

[13] United Nations Development Program, "Public administration sector study in Bangladesh”, Dhaka: UNDP, 1993.

[14] World Bank, "Bangladesh: government that works reforming the public sector", Dhaka: United Press Limited, 1996.

[15] Asian Development Bank (ADB), "Report and Recommendation of the President to the Board of Directors: Proposed Program Loan and Technical Assistance Grant for the People's Republic of
Bangladesh,” Good Governance Program, Dhaka: ADB Bangladesh, 2007.

[16] A. E. Sarker and R. Pathak, "New Public Management: An Analytical Review," Productivity, Vol. 41, No. 1, 2000, pp. 56-65.

[17] A. E. Sarker, "New Public Management in Bangladesh: Chasing A Mirage?”, Indian Journal of Public Administration, Vol. XLVII, No. 2, 2001, pp. 154-169.

[18] A. E. Sarker, "New Public Management in Developing Countries: An Analysis of Success and Failure with Particular Reference to Singapore and Bangladesh,” International Journal of Public Sector Management, Vol. 19 No. 2, pp. 180-203, Emerald Group Publishing Limited, 2006.

[19] K. Siddiqui, "Towards Good Governance in Bangladesh: Fifty Unpleasant Essays,” University Press, Dhaka, 1996.

[20] H. Zafarullah, "Public Administration in Bangladesh: Political and Bureaucratic Dimensions," in Tummala, K.K. (Ed.), Comparative Bureaucratic Systems, Lexington Books, Lexington, MA, 2003, pp. 265-88.

[21] A. T. M. Huda and M. A. Rahman, "Delay in Disposal of Cases: A Structural Analysis of the Bangladesh Secretariat," Savar, Bangladesh: Public Administration Training Center. Mimeo, 1989.

[22] R. Sobhan, "Structural Dimensions of Malgovernance in Bangladesh,” Economic and Political Weekly, September, Vol. 4, 2004, pp. 1-17.

[23] B. Ray, "Good Governance, Administrative Reform and Socio-economic Realities: A South Pacific Perspective," International Journal of Social Economics, Vol. 26, 1999, pp. 354-69. doi:10.1108/03068299910229749

[24] M. Turner and D. Hulme, "Governance, Administration and Development,” West Hartford, Conn: Kumarian press, 1997. 